\title{
REVIEW
}

\section{MUSHROOM CULTIVATION IN BRAZIL: CHALLENGES AND POTENTIAL FOR GROWTH}

\author{
Cultivo de cogumelos no Brasil: desafios e potencialidades
}

\author{
Eustáquio Souza Dias ${ }^{1}$
}

\begin{abstract}
Mushroom cultivation is rapidly expanding in Brazil because Brazilians have discovered the medicinal and culinary value of mushrooms and their economic situation has improved. However, the horticultural technology for cultivating mushrooms under Brazilian conditions is lacking. For many years, the mushroom cultivation technology used in Brazil was adapted from developed countries whose materials and climate were different from those of Brazil. In order to exploit the Brazilian potential for mushroom cultivation it is essential to develop cultivation technology for family owned and operated rustic farms as well as for modern large scale industrial operations. Mushroom species cultivated in Brazil are discussed and some approaches for future research are suggested.
\end{abstract}

Index terms: Mushroom compost, casing layer, mushroom fruiting, Agaricus, Pleurotus, Lentinula.

\section{RESUMO}

O cultivo de cogumelos está em franca expansão no Brasil, graças à descoberta de suas propriedades medicinais e culinárias pelo povo brasileiro e também em função da melhoria das condições econômicas. Entretanto, há ainda uma necessidade de desenvolvimento de uma tecnologia de cultivo apropriada para as condições brasileiras. Durante muitos anos, a tecnologia de cultivo de cogumelos utilizada no Brasil foi uma adaptação daquela utilizada nos países desenvolvidos, cujas condições climáticas e disponibilidade de matéria-prima são diferentes do Brasil. Portanto, para que se possa desenvolver todo o potencial brasileiro para o cultivo de cogumelos, é essencial o desenvolvimento de tecnologias de cultivo mais apropriadas para a agricultura familiar, mas também é importante o desenvolvimento tecnológico voltado para o cultivo de cogumelos em escala industrial. As principais espécies de cogumelos cultivados no Brasil são discutidas neste trabalho, além da indicação das principais necessidades de pesquisa para o futuro.

Termos para indexação: Composto de cultivo, camada de cobertura, indução da frutificação, Agaricus, Pleurotus, Lentinula.

\section{(Received in june 6, 2010 and approved in july 28, 2010)}

\section{Introduction}

Brazil is not a country with a tradition in mushroom cultivation. Of all the countries with Latin origins, Portugal is uniquely devoid of a culture of edible mushroom consumption. France has become famous for the origin of the "Champignon de Paris", the most widely cultivated and consumed mushroom worldwide. The consumption of wild mushrooms, such as "porcini", is famously appreciated in Italy. Spain presently has one of the main mushroom research centers, highlighting Agaricus bisporus ("Champignon de Paris"). Unfortunately, Portugal did not contribute a culture of mushroom consumption to Brazil, and probably because of this, most Brazilians have developed a prejudice against mushrooms, believing they are poisonous or hallucinogenic.

Only in the first half of the 20th century did this reality begin to change, more than 400 years after colonization began in Brazil. The onset of this change was Asian migration, when mostly Japanese and Chinese arrived in great numbers, especially in the State of São Paulo. Among the immigrants who established themselves in rural areas, some brought from their birthplaces mushroom cultivation practices used by their ancestors. These immigrant activities were so important for mushroom introduction in Brazil that São Paulo quickly became a great reference center for mushroom cultivation in Brazil. It was considered for a long time to be the only state in which this activity had economic relevance. Nowadays, it is still the greatest mushroom producer in Brazil. However, this activity was also developed according to traditional practices. For this reason, mushroom cultivation in Brazil was originally restricted to small rural properties that used family labor and rudimentary technology that was passed on this way from generation to generation.

${ }^{1}$ Federal University of Lavras/UFLA - Department of Biology - Laboratory of Edible Mushrooms - P.O. Box 3037 - 37200-000 - Lavras, MG - Brazil esdias@dbi.ufla.br 
In this scenario, a person emerged who became one of the greatest icons for mushroom cultivation in Brazil. Mr. Oscar Molena, an Italian living in Brazil, traveled to his birthplace in search of technology and scientific knowledge that might enable the development of mushroom cultivation practices in Brazil. In addition to his own mushroom farming, Mr. Molena became a reference and promoter of the activity to those who were interested. He also published a book aimed at presenting modern technologies and practices to Brazil, using language accessible to rural producers (Molena, 1986).

After that, people such as Dr. Vera Bononi, Dr. Arailde F. Urben and Prof. Augusto Eira contributed greatly to spreading mushroom cultivation in Brazil; their research publications have provided references for producers as well as new researchers who dedicate themselves to this interesting and pleasant activity (Bononi et al., 1995; Urben, 2001; Eira, 2003). Recently, mushroom cultivation has started receiving more attention by the Brazilian scientific and academic community. The main promising species for cultivation in Brazil are discussed below.

\section{"Champignon de Paris" (Agaricus bisporus)}

In spite of the fact that mushroom cultivation has been practiced for over a millennium and there still are reports of first trials of controlled cultivation in Chinese traditions, industrial cultivation of edible mushrooms has been developed for the species Agaricus bisporus, which was originally discovered near Paris, France. In 1707, the first report of a cultivation technique for this mushroom was made (Chang \& Miles, 2004). Since then, cultivation practices for this mushroom have evolved greatly. Currently, its cultivation is an industrial activity, highly technical in the developed countries where it is produced. On the other hand, in developing countries, its cultivation has been conducted under low technology for many years, as an activity requiring family labor and resulting in low production levels (Chang \& Miles, 2004). However, in these same countries (including Brazil), with an increase in demand, an increase in the number of companies that use cultivation houses with temperature, humidity and aeration control has also occurred.

A great advancement for A. bisporus mushroom cultivation occurred when it was observed that horse manure (mixing feces and urine with wheat straw) is an excellent substrate for compost preparation for mushroom cultivation (Flegg et al., 1986). With the development of the automotive industry and consequent scarcity of horse manure in the beginning of the 20th century, a new advancement was made in the development of composting formulations that use wheat straw and other agricultural residues with sources of nitrogen, such as nitrate, ammonia and urea. The composting process was also improved when it was discovered that conditioning at a temperature between $50^{\circ} \mathrm{C}$ and $60^{\circ} \mathrm{C}$ was important not only to eliminate pests, illnesses and contaminants, but also for guaranteeing compost quality and, consequently, making mushroom cultivation more productive (Flegg et al., 1986). As a result, much research has been aimed at understanding the role of microorganisms involved in the composting process (Fergus, 1964; Straatsma et al., 1989, 1994; Epstein, 1997; Salar \& Aneja, 2007a,b). These studies have demonstrated that an appropriate microbial succession is essential for obtaining a selective compost of good quality. On the other hand, little is known about the microbiota present in compost produced in Brazil. Some initial work has been done, examining only phase I composting for the cultivation of the mushroom A. brasiliensis (Dias et al., 2009; Silva et al., 2009). However, there are no studies about microbiota phase II, which is responsible for compost conditioning and, therefore, the final quality of it. The identification of these microorganisms in Brazilian compost and the selection of the most important strains for the composting process might be very important for increasing A. bisporus production, which is still very inferior when compared to the levels reached by developed countries.

The establishment of a technology for compost preparation and the development of mushroom spawn production technology enabled the achievement of stable production practices that are less susceptible to great variations in productivity (Chang \& Miles, 2004). Currently, there are different strains in the international market. However, little is known about the origins of those used in Brazil because, here, spawn trading was made by small companies with low technological resources for monitoring the genetic and sanitary quality of commercialized strains. Therefore, in the future, it will be important that specialized laboratories do this work to avoid strains that have been degenerated or contaminated by viruses or other infectious elements.

Another aspect that differentiates the cultivation of $A$. bisporus in Brazil from that in European countries and North America is the difficulty associated with using high quality peat as a casing layer. After the cultivation compost is totally colonized, it is essential for it be covered by a material with specific physicochemical characteristics, and probably one that is also microbiologically appropriate, in order to provide high levels of mushroom production. For many years, different kinds of sterilized soils and 
subsoils were used for this purpose. However, the variability in their effectiveness was considerable, until it was established that peat moss is one of the best casing layer materials (Chang \& Miles, 2004). In Brazil, peat is used in some regions; however, in contrast with other countries, this material is not so abundant and its quality is not always appropriate for this purpose. So, it is still very common to use soil for a casing layer (Eira, 2003). Evaluations of alternative materials for casing layers, as well as methods for disinfection treatments for these materials, are very important for making the induction of mushroom primordia formation more efficient. In addition to this, considering that different bacterial species (including pathogenic ones) are present in different kinds of Brazilian soils, the study of the microbiota present in different casing layers might also be an important research area.

Technological advances have permitted mushroom cultivation to be done under controlled conditions, guaranteeing production throughout the year. In contrast, without environmental controls, mushroom cultivation is restricted to months with mild temperatures (Chang \& Miles, 2004). For developing countries, using modern cultivation houses with controlled environments means high production costs. For this reason, in these countries it is possible to find several different cultivation house models, made according to the investment capacity of local producers (Oei, 2003). In Brazil, although there are enterprises that use controlled cultivation systems, most of the producers still count on milder seasons that are conducive to cultivation in simpler and cheaper facilities. Due to this, mushroom production is still subject to seasonality, which brings certain obstacles to expanding this activity.

Consumption of A. bisporus in Brazil has been consolidated in the form of a canned product. There is no habit of consuming fresh mushrooms, as happens in other countries. For a smaller Brazilian producer, this might be an important market niche in the future because the fresh product does not demand processing and does not have strict requirements of Brazilian authorities because it is a natural product, marketed the same way as vegetables. However, in order to make this happen in the future, it will be very important that producers search for resources so they can guarantee a continuous supply to supermarkets, restaurants or directly to consumers. In this context, the participation of research institutions could be determinative as much in the adaptation of new lineages as in the development of technologies for climate control of cultivation environments that are simpler and have lower costs.

\section{Medicinal mushroom (Agaricus brasiliensis)}

The mushroom Agaricus brasiliensis, also known as A. blazei or A. subrufescens (Wasser et al., 2002; Kerrigan, 2005; Dias et al., 2008), has received great interest since the end of the 20th century, and several papers were recently published highlighting its medicinal properties (Kawagishi et al., 1989; Mizuno et al., 1990a,b, 1995; Ito et al., 1997; Kaneno et al., 2004; Mizuno \& Kawakami, 2006; Fan et al., 2007; Firenzuoli et al., 2008).

Thanks to a great marketing strategy in Japan, this mushroom known as either medicinal mushroom or Sun Mushroom ${ }^{\circledR}$ (Cogumelo do Sol ${ }^{\circledR}$ in Portuguese) in Brazil has obtained relevance there. Japan has become the greatest importer of these mushrooms produced in Brazil (Dias et al., 2004). Since then, many Brazilian farmers, and many people without any prior experience with agricultural activity, have realized the promise of cultivating this mushroom, generating a strong expansion of its cultivation in several regions of Brazil. This expansion has increased the popularity of this mushroom species in the country and Brazilians' knowledge of the medicinal properties not only of this species but also of other edible mushroom species. Nevertheless, people without proper qualifications who also began cultivating this mushroom later suffered great losses, mainly due to false advertisements by "specialists" in the area, which led to the contamination of these cultivation activities by unscrupulous economic interests. This scenario began to change in 2006, when a great decline in Japanese importations occurred due to problems found in mushrooms imported from other countries, which made the mushrooms harmful to human health (SECOM, 2010). Although the Brazilian product was considered of higher quality, this did not prevent a decrease in Japanese consumption. Consequently, importations fell drastically, causing most Brazilian producers to give up production. A positive outcome was that a large portion of the unethical professionals, as well as the unprepared and unqualified, also gave up their activities.

The decline in Japanese importations occurred for three consecutive years (2006 to 2008), and the market suffered a loss of 76\% (SERCOM, 2010). In 2009, the market stabilized, with a slight increase in exportations. It is not possible to predict whether the market will return to the levels of 2004; however, producers who maintained their A. brasiliensis cultivation activities have now found economically favorable conditions for this mushroom's cultivation. This has occurred firstly because exportation to Japan continues, although with less intensity, and also because there has been an increase in demand in the Brazilian market, either for consumption in the form of tea or for sale as capsules. 
Besides the consumption of dry A. brasiliensis for medicinal purposes, it also has great potential for its culinary uses, which might increase its consumption even further (Escouto et al., 2005). In light of the current situation regarding its potential for consumption and the importance this mushroom had in changing perceptions of Brazilian consumers with respect to edible and medicinal mushroom consumption, it is important to continue research aimed at improving cultivation techniques for this species.

Cultivation of $A$. brasiliensis presents several similarities to $A$. bisporus. The main difference is that the first does not need a reduction in temperature for fructification, whereas $A$. bisporus requires a temperature below $20^{\circ} \mathrm{C}$ during the fructification period (Dias et al., 2004). However, it is probable that due to different ecological conditions between their origin countries, it is still necessary to develop a proper technology for cultivating this mushroom because its production level is still very low compared to that of $A$. bisporus (Siqueira et al., 2009). Therefore, several research projects have been developed that aim to find better composting processes and casing layer materials (Silva, E. et al., 2007, 2009; Cavalcante et al., 2008; Siqueira et al., 2009; Colauto et al., 2010), as well as to determine the genetic diversity of different strains used in the country (Colauto et al., 2002; Tomizawa et al., 2007). Besides this research, this species also probably has a life cycle different from classic dicariotic basidiomycetes, which makes it an excellent research system for elucidating the sexual behavior of atypical basidiomycetes (Dias et al., 2008).

\section{Pleurotus mushrooms (Shimeji, Hiratake, Brown Hiratake )}

Pleurotus is certainly the most prodigal fungi genus to offer species of edible mushrooms, and this genus is responsible for the third most widely produced kind of mushroom in the world, popularly known as oyster mushrooms. Besides producing high culinary value mushrooms, they are also relatively easy and quick to cultivate, not only because they are fast growing but also because of their capacity to colonize crude substrates such as tree logs, cereal straw and other agricultural residues. In contrast to Agaricus mushrooms, they do not need compost for cultivation.

Among the different species of the genus, $P$. ostreatus is the most widely known and well studied in the entire world. It is known as shimeji in Brazil when it is harvested while still in the primordium stage. These mushrooms are characterized by a bland flavor, depending on the kind of preparation, which makes them very interesting for people who are not used to eating mushrooms. Different strains are known and cultivated, producing mushrooms of different colors. In Brazil, two strains of $P$. ostreatus are cultivated preferentially. The first strain produces gray mushrooms. The second one produces white mushrooms known as "Hiratake" when these mushrooms are harvested with well-developed pileus, or white shimeji when harvested in the primordium stage. This species (and others in this genus) is normally characterized by a need for a colder environment (usually under $20^{\circ} \mathrm{C}$ ) to begin fruiting, requiring that cultivation takes place in the colder seasons of the year. Alternatively, an environment with a temperature control may be used to guarantee continuous production.

Pleurotus eryngii, known as Cardoncello or "King oyster" mushrooms in English-speaking countries, is another species that demands a colder environment for fructification. This might require a greater investment for its continuous production. In spite of this, it is a species with great potential in Brazil because it has a harder consistency. Thus, it lasts a longer time on a shelf and is highly appropriate for use on grills, with a good and bland flavor, independent of preparation conditions. In Canada, this mushroom is also produced under controlled conditions, allowing for development of the stipe in relation to its pileus to reflect market preferences. In Brazil, without appropriate control of environmental conditions, the mushroom usually has a more developed pileus. However, this is not a problem because national markets do not show any restrictions in relation to pileus development. On the other hand, it is important to highlight that the market for this mushroom is still very limited, in spite of its great potential. As for other species in this genus, its cultivation is easily obtained on sawdust-based substrates. It is important to keep the temperature below $20^{\circ} \mathrm{C}$, as tests carried out in Brazil have shown that they fructify well at $19^{\circ} \mathrm{C}$. This temperature might occur naturally in the autumn and spring seasons, depending on the cultivation region. However, to increase its production, it will be important to study in more detail the factors involved in this mushroom's fructification and morphology, and it could become one of the best options for the Brazilian market.

Pleurotus sajor-caju, known as "Houbitake" or brown "hiratake" in Brazil, is a species little cultivated in Brazil or the rest of the world compared to other species in this genus. However, it has great potential, especially for smaller producers. Besides its nice bland flavor, similar to other Pleurotus species, it is probably the most appropriate species known for cultivation in tropical and subtropical countries (Chang \& Miles, 2004). This species can be 
cultivated practically in all Brazilian territories, and it may be cultivated all year long in the hotter regions without the need for a large investment in infrastructure.

Pleurotus mushrooms can be cultivated on logs of some tree species (Molena, 1986; Chang \& Miles, 2004). However, the traditional procedure for this mushroom's cultivation is to use pasteurized compost steam (Molena, 1986; Obodai et al., 2003). On the other hand, these mushrooms exhibit great versatility and fast colonization rates, so several alternative cultivation techniques have been proposed. Some propose using either hot or chemical treatments to disinfect substrates without using composting, whereas others suggest using compost but without a pasteurization process (Hernández et al., 2003; Contreras et al., 2004; Mandeel et al., 2005). These procedures are not sufficient to eliminate all of the microorganisms present in a substrate; nevertheless, they can reduce contaminants to a level that permits mushroom mycelia to colonize all of a substrate competitively. Although there are a lot of alternative procedures for substrate preparation, most of the papers published by the Brazilian scientific community report a preference for axenic cultivation, i.e., cultivation in a substrate previously sterilized in an autoclave, with some variations (Dias et al., 2003; Pedra \& Marino, 2006; Silva, V. et al., 2007; Marino et al., 2008; Gonçalves et al., 2010).

Of all of the procedures used to prepare cultivation substrates for these mushrooms, the most appropriate technique for smaller producers in Brazil is a short composting step followed by steam pasteurization. This technique is easy for small producers to execute because it does not demand a large investment and may be scaled according to the intended production volume. In addition to its ease of use, short composting allows for the occurrence of microbial succession in the compost, similar to what happens when preparing Agaricus substrates. This succession guarantees a rich microorganism diversity, which promotes a balance in the final product and inhibits the predominance of any particular contaminating species (Chang \& Miles, 2004). At the end of the short composting process, the compost is subjected to severe steam pasteurization to reduce the microbial community and eliminate pests and diseases. Compost prepared in this way permits spawn to grow quickly and vigorously, and contamination problems are minimized during the mushroom production cycle.

In spite of all these advantages, this technique has not spread into Brazilian academic institutions, possibly because for most institutions the use of axenic cultivation is more convenient once these institutions already have the entire necessary laboratory infrastructure. In contrast, the implementation of a composting method would require completely different infrastructure. In addition to this drawback, composting generates a dirty and ugly environment, which is a great inconvenience and unpleasant to most researchers, who are more used to the organized and clean environment of research laboratories. For this reason, most research studies conducted for Pleurotus mushrooms in Brazil are disassociated from the realities of small Brazilian producers with low investment capacities.

\section{Shiitake (Lentinula edodes)}

The shiitake mushroom is probably the second most widely cultivated and consumed mushroom in the world. Sometimes the oyster mushroom is regarded as the second most cultivated group in the literature; however, this group is composed of different species in the Pleurotus genus. Therefore, when each species is considered individually, Lentinula edodes occupies second place in the mushroom world market.

Shiitake have a more distinct flavor than Pleurotus, and this flavor is more appreciated by many consumers. The growing market for this mushroom in Brazil testifies to its potential as an exquisite mushroom that differs from others. Years ago, producers beginning its production could hardly display their produce at the main consumption centers (Rio de Janeiro, São Paulo and Brasília) and the market was very limited. Nowadays, there is a scarcity of the product in those same consumption centers, and there is also a greatly expanding market in the state of Minas Gerais. The deficiency in the supply to this market is so vast that there are consumers who still have only purchased the product in its dried form. This demonstrates that, with good planning and an appropriate technological base, the production of shiitake might be increased in the State of Minas Gerais to supply the local market as well as other states where demands are also still higher than supplies. In this context, the South region of Minas Gerais may occupy an outstanding position because it has weather appropriate for the cultivation of shiitake.

For many years, shiitake was cultivated in native logs from its country of origin. In Brazil, cultivation of this mushroom in eucalyptus logs was adapted, which represented a great advance because eucalyptus is considered a renewable resource and, therefore, prevents the use of native species. Some years later, a new method was proposed. It is known as the Jun-Cao technique (previously discussed for the Pleurotus mushroom) and is based on the cultivation of mushrooms in grass-based 
substrates. However, as previously highlighted, this technique demands a greater investment for obtaining substrate and acquiring a more controlled cultivation environment to avoid high contamination levels. One alternative to grass-based substrates is the use of eucalyptus sawdust, which has become more abundant as a function of the use of crescent eucalyptus by the wood industry. Thanks to the great availability of this residue, axenic cultivation in sawdust has become the subject of studies aimed at making it quicker and more efficient (Diehle \& Royse, 1986; Royse \& Bahler, 1986).

According to these studies, blocks of sawdust must be incubated during the colonization phase for at least three months before the fructification-inducing phase in order to obtain greater productivity. The success of shiitake cultivation with these conditions has allowed it to become one of the most widely used methodologies. Therefore, in spite of its restriction to smaller producers, some companies in São Paulo have begun relying on this cultivation strategy because log cultivations do not always respond well to fructification-inducing procedures, which makes producers insecure because they have to fulfill their supply contracts.

Because substrate preparation, sterilization and inoculation are very hard for an ordinary producer, a market has arisen for suppliers that provide colonized substrate blocks ready for the induction of fructification and subsequent cultivation of shiitake mushrooms. Although this system has worked reasonably well, it has some limitations, especially because it uses an axenic cultivation system that can result in high contamination levels. For this reason, it would be worthwhile to develop more selective substrates that permit shiitake mushroom development but not the growth of fast growing fungi, which normally occurs in the blocks during the cultivation phase and, sometimes, even during the substrate colonization phase.

Another extremely important aspect of shiitake cultivation in axenic systems is the induction of mushroom fructification. The most widely used system is to immerse a colonized block in water, as is done in log cultivation systems. For this approach, it is necessary that a mycelial mass develop intensively around all of a sawdust block, creating a brown coriaceous cover. This browning process protects the block from moisture loss and contamination. This induction system is very simple and does not demand a great investment; however, it has at least two disadvantages. The first disadvantage is that it allows contaminants to spread when one or more blocks contain contaminants not yet noticeable by the human eye. This problem becomes worse during the second production flush, when blocks are exposed to the environment and subject to more contamination. The second disadvantage related to this system is that the browning process is not always complete three months after substrate colonization, causing a producer to extend the incubation time, consequently causing a delay in production. In addition to these disadvantages, soaking blocks without a good brown cover may lead to the disintegration of the substrate and cause major contamination problems.

Considering the problems associated with submerging the colonization block, using a thermal shock without soaking is a convenient alternative, although it demands investment in a temperature-controlled environment. Some information on the necessary conditions for the induction of shiitake fructification has been presented in the literature. Although some other physical, chemical and biological factors are relevant (Shin et al., 1997; Ohga \& Royse, 2001), the main factor for inducing fructification in axenic cultivation methods is temperature. After substrate colonization and the browning process, blocks must be transferred to an environment between 15 and $19^{\circ} \mathrm{C}$ (Royse \& Bahler, 1986).

Ohga \& Royse (2001) reported using a temperature reduction from 22 to $15^{\circ} \mathrm{C}$ to induce Lentinula edodes fructification in the first flush; however, the authors mentioned that for the second flush, blocks were immersed in water at $18^{\circ} \mathrm{C}$ for 24 hours. According to Royse (2001), when browning is carried out outside of the bag, it is important to soak blocks in water at $12^{\circ} \mathrm{C}$ for 3 to 4 hours. However, when blocks are browned inside the bags, soaking is not necessary because, according to the author, the blocks already have enough water to support the first flush under these conditions. However, soaking is necessary for subsequent flushes.

The information presented above clearly demonstrates that soaking is important not for properly inducing fructification, but for replacing water that is lost during substrate colonization and, mainly, during mushroom production. Considering this, experimenting with materials with higher water absorption capacities could be very interesting for attempting to formulate a substrate with a higher amount of moisture to allow for a greater number of flushes without the need for soaking.

\section{Conclusions}

Mushroom biology and cultivation is an area of science in expansion in Brazil. There are a great number of scientists working at different colleges, universities and research companies on research projects on edible and 
medicinal mushrooms. This expansion is a reflection of a recent change that occurred in Brazilian society's feeding habits, which is due to the discovery of the medicinal and culinary value of mushrooms by Brazilians, as well as the improvement of their quality of life in general. Therefore, mushroom cultivation in Brazil is expected to continue to develop, in spite of all of the difficulties encountered, in order to meet the demands of a market in continuous expansion. For this reason, the cultivation of mushrooms should be targeted for research incentives by government agencies as a familiar agricultural activity because, in an agricultural context, few products have an aggregate value as high as edible mushrooms.

\section{Acknowledgements}

The author thanks the Brazilian agencies "Fundação de Amparo a Pesquisa de Minas Gerais" (FAPEMIG) and "Coordenação de Aperfeiçoamento de Pessoal de Nível Superior" (CAPES) for their financial support.

\section{REFERENCES}

BONONI, V.L.; CAPELARI, M.; MAZIERO, R.; TRUFEM, S.F.B. Cultivo de cogumelos comestíveis. São Paulo: Ícone, 1995. 206p.

\section{CAVALCANTE, J.L.R.; GOMES, V.F.F.; KOPYTOWSKI} FILHO, J.; MINHONI, M.T.A.; ANDRADE, M.C.N. Cultivation of Agaricus blazei in the environmental protection area of the Baturité region under three types of casing soils. Acta Scientiarum/Agronomy, Maringá, v.30, n.4, p.513-517, 2008.

CHANG, S.T.; MILES, P.G. Mushrooms: cultivation, nutritional value, medicinal effect, and environmental impact. Boca Raton: CRC, 2004. 451p.

COLAUTO, N.B.; SILVEIRA, A.R.; EIRA, A.F.; LINDE, G.A. Alternative to peat for Agaricus brasiliensis yield. Bioresource Technology, Amsterdam, v.101, p.712-716, 2010 .

COLAUTO, N.C.; DIAS, E.S.; GIMENES, M.A.; EIRA, A.A. Genetic characterization of isolates of the basidiomycete Agaricus blazei by RAPD. Brazilian Journal of Microbiology, São Paulo, v.33, n.2, p.131-133, Apr./June 2002.

CONTRERAS, E.P.; SOKOLOV, M.; MEJÍA, G.; SÁNCHEZ, J.E. Soaking of substrate in alkaline water as a pretreatment for the cultivation of Pleurotus ostreatus.
Journal of Horticultural Science \& Biotechnology, New York, v.79, n.2, p.234-240, 2004.

DIAS, E.S.; ABE, C.; SCHWAN, R.F. Truths and myths about the mushroom Agaricus blazei. Scientia Agricola, Piracicaba, v.61, n.5, p.545-549, Sept./Oct. 2004.

DIAS, E.S.; GUIMARÃES, S.E.; SIQUEIRA, F.G.; SILVA, R.; BATISTA, L.R. Allergenic and toxigenic fungi in the compost of cultivation of Agaricus brasiliensis. Scientia Agraria, Curitiba, v.10, n.6, p.507-511, Nov./Dec. 2009.

DIAS, E.S.; KOSHIKUMO, E.M.S.; SCHWAN, R.F.; SILVA, R. Cultivo do cogumelo Pleurotus sajor-caju em diferentes resíduos agrícolas. Ciência e Agrotecnologia, Lavras, v.27, n.6, p.1363-1369, 2003.

DIAS, E.S.; LABORY, C.R.G.; HERRERA, K.M.S.; ALVES, A.A.; TORRES, G.A.; RINKER, D.L. Cytological studies of Agaricus brasiliensis. World Journal of Microbiology and Biotechnology, New York, v.24, p.24732479, 2008.

DIEHLE, D.A.; ROYSE, D.J. Shiitake cultivation on sawdust: evaluation of selected genotypes for biological efficiency and mushroom size. Mycologia, v.78, n.6, p.929-933, Nov./Dec. 1986.

EIRA, A.F. Cultivo do cogumelo medicinal Agaricus blazei (Murril) ss. Heinemann ou Agaricus brasiliensis (Wasser et al.). Viçosa: Aprenda Fácil, 2003. 390p.

EPSTEIN, E. The science of composting. Boca Raton: CRC, 1997. 487p.

ESCOUTO, L.F.S.; COLAUTO, N.B.; LINDE, G.A.; AIZONO, P.M.; CARVALHO, L.R.M.; EIRA, A.F. Acceptability of the sensory characteristics of the brazilian mushroom Agaricus brasiliensis. Brazilian Journal of Food Technology, v.8, n.4, p.321-325, Oct./Dec. 2005.

FAN, L.F.; SOCCOL, A.T.; PANDEY, A.; SOCCOL, C.R. Effect of nutritional and environmental conditions on the production of exo-polysaccharide of Agaricus brasiliensis by submerged fermentation and its antitumor activity. LWT - Food Science and Technology, v.40, p.30-35, 2007.

FERGUS, C.L. Thermophilic and thermotolerant molds and actinomycetes of murshroom compost during peak heating. Mycologia, v.56, p.267-284, 1964. 
FIRENZUOLI, F.; GORI, L.; LOMBARDO, G. The medicinal mushroom Agaricus blazei murrill: review of literature and pharmaco-toxicological problems. eCAM, v.5, n.1, p.3-15, 2008.

FLEGG, P.B.; SPENCER, D.M.; WOOD, D.A. The biology and technology of the cultivated mushroom. Chicester: J.Wiley, 1986. 347p.

GONÇALVES, C.C.M.; PAIVA, P.C.A.; DIAS, E.S.; SIQUEIRA, F.G.; HENRIQUE, F. Evaluation of the cultivation of Pleurotus sajor-caju (fries) sing. on cotton textile mill waste for mushroom production and animal feeding. Ciência e Agrotecnologia, Lavras, v.34, n.1, p.220-225, jan./fev. 2010.

HERNÁNDEZ, D.; SÁNCHEZ, J.E.; YAMASAKI, K. A simple procedure for preparing substrate for Pleurotus ostreatus cultivation. Bioresource Technology, Amsterdam, v.90, p.145-150, 2003.

ITO, H.; SHIMURA, K.; ITOH, H.; KAWADE, M. Antitumor effects of a new polysaccharide-protein complex (ATOM) prepared from Agaricus blazei (Iwade strain 101) "Himematsutake" and its mechanism in tumorbearing mice. Anticancer Research, v.17, p.277-284, 1997.

KANENO, R.; FONTARI, L.M.; SANTOS, S.A. Effect of extracts from Braziliam sun-mushroom (Agaricus blazei) on the NK activity and lymphoproliferative responsiveness of Ehrlich tumor-bearing mice. Food and Chemical Toxicology, v.42, p.909-916, 2004.

KAWAGISHI, H.; INAGAKI, R.; KANAO, T.; MIZUNO, T. Fractionation and antitumor activity of the waterinsoluble residue of Agaricus blazei fruiting bodies. Carbohydrate Research, v.186, p.267-273, 1989.

KERRIGAN, R.W.Agaricus subrufescens, a cultivated edible and medicinal mushroom, and its synonyms. Mycologia, v.97, p.12-24, 2005.

MANDEEL, Q.A.; AL-LAITH, A.A.; MOHAMED, S.A. Cultivation of oyster mushrooms (Pleurotus spp.) on various lignocellulosic wastes. World Journal of Microbiology \& Biotechnology, London, v.21, p.601-607, 2005.

MARINO, R.H.; ABREU, L.D.; MESQUITA, J.B.; RIBEIRO, G.T. Crescimento e cultivo de diferentes isolados de Pleurotus ostreatus (Jacq.: fr.) Kummer em serragem da casca de coco. Arquivos do Instituto Biológico, São Paulo, v.75, n.1, p.29-36, jan./mar. 2008.

MIZUNO, T. Kawariharatake, Agaricus blazei Murrill: medicinal and dietary effects. Food Reviews International, Madison, v.11, n.1, p.167-172, 1995.

MIZUNO, T.; HAGIWARA, T.; NAKAMURA, T.; ITO, H.; SHIMURA, K.; SUMIYA, T.; ASAKURA, A. Antitumor activity and some properties of water-soluble polysaccharides from 'Himematsutake', the fruiting body of Agaricus blazei Murrill. Agricultural and Biological Chemistry, New York, v.54, p.2889-2896, 1990a.

MIZUNO, T.; INAGAKI, R.; KANAO, T.; HAGIWARA, T.; NAKAMURA, T.; ITO, H.; SHIMURA, K.; SUMIYA, T.; ASAKURA, A. Antitumor activity and some properties of water-insoluble hetero-glycans from 'Himematsutake', the fruiting body of Agaricus blazei Murrill. Agricultural and Biological Chemistry, New York, v.54, p.2897-2905, 1990b.

MIZUNO, M.; KAWAKAMI, S. An immunomodulating polysaccharide in Agaricus brasiliensis S. Wasser et al. (Agaricomycetidae) activates macrophages through tolllike receptor 4. International Journal of Medicinal Mushrooms, v.8, n.3, p.223-229, 2006.

MOLENA, O. O moderno cultivo de cogumelos. São Paulo: [s.n.], 1986. 170p.

OBODAI, M.; CLELAND-OKINE, J.; VOWOTOR, K.A. Comparative study on the growth and yield of Pleurotus ostreatus mushroom on different lignocellulosic byproducts. Journal of Industrial Microbiology and Biotechnology, v.30, p.146-149, 2003.

OEI, P. Mushroom cultivation: appropriate technology for mushroom growers. Leiden: Backhuys, 2003. 429p.

OHGA, S.; ROYSE, D.J. Transcriptional regulation of laccase and cellulase genes during growth and fruiting of Lentinula edodes on supplemented sawdust. FEMS Microbiology Letters, Amsterdam, v.201, p.111-115, 2001.

PEDRA, W.N.; MARINO, R.H. Cultivo axênico de Pleurotus spp. em serragem da casca de coco (Cocos nucifera Linn.) suplementada com farelo de arroz e/ou de trigo. Arquivos do Instituto Biológico, São Paulo, v.73, n.2, p.219-225, abr./jun. 2006. 
ROYSE, D.J. Cultivation of shiitake on natural and synthetic logs. New York: College of Agricultural Sciences, 2001. 12p.

ROYSE, D.J.; BAHLER, C.C. Effects of genotype, spawn run time, and substrate formulation on biological efficiency of shiitake. Applied and Environmental Microbiology, v.52, n.6, p.1425-1427, 1986.

SALAR, R.K.; ANEJA, K.R. Significanse of thermophilic fungi in mushroom compost preparation: effects on growth and yield of Agaricus bisporus (Lange) Sing. Journal of Agricultural Technology, v.3, n.2, p.241-253, 2007a.

SALAR, R.K.; ANEJA, K.R. Thermophilic Fungi: taxonomy and biogeography. Journal of Agricultural Technology, v.3, n.1, p.77-107, 2007 b.

SECOM. Boletim de mercado o mercado de cogumelo "Agaricus blazei Murril" (Himematsutake) no Japão. Tokyo: Embaixada do Brasil em Tóquio, 2010. 8p. Disponível em: <http://www.brasemb.or.jp/portugues/ 'economy/pdf/Āgaricus10.pdf . Acesso em: 10 jan. 2009.

SHIN, G.G.; MEGURO, S.; KAWACHI, S. The active constituent in yeast extract for fruit body formation of Lentinula edodes. Canadian Journal of Microbiology, Ottawa, v.43, p.1202-1204, 1997.

SILVA, C.F.; AZEVEDO, R.S.; BRAGA, C.; SILVA, R.; DIAS, E.S.; SCHWAN, R.F. Microbial diversity in a bagasse-based compost prepared for the production of Agaricus brasiliensis. Brasilian Journal of Microbiology, São Paulo, v.40, p.590-600, 2009.

SILVA, E.G.; DIAS, E.S.; SIQUEIRA, F.G.; SCHWAN, R.F. Chemical analysis of fructification bodies of Pleurotus sajor-caju cultivated in several nitrogen concentrations. Ciência e Tecnologia de Alimentos, Campinas, v.27, n.1, p.72-75, jan./mar. 2007.

SILVA, V.A.; DIAS, E.S.; VALE, R.H.P.; SILVA, R.; MOREIRA, G.F. Isolation and identification of bacteria present in the casing layer utilized to the cultivation of the mushroom Agaricus blazei Murril. Ciência e Agrotecnologia, Lavras, v.31, n.5, p.1364-1373, set./out. 2007.

SIQUEIRA, F.G.; DIAS, E.S.; SILVA, R.; MARTOS, E.T.; RINKER, D.L. Cultivation of Agaricus blazei ss. Heinemann using different soils as source of casing materials. Scientia Agricola, Piracicaba, v.66, n.6, p.827830, Nov./Dec. 2009.

STRAATSMA, G.; GERRITS, J .P.G.; AUGUSTIJN, M.P.A.M.; OPDENCAMP, H.J.M.; VOGELS, G.D.; GRIENSVEN, L.J.L.D. van. Population dynamics of Scytalidium thermophilum in mushroom compost and stimulatory effects on growth rate and yield of Agaricus bisporus. Journal of General Microbiology, v.137, p.1471-1477, 1989.

STRAATSMA, G.; SAMSON, R.A.; OLIJNSMA, T.W. OPDENCAMP, H.J.M.; GERRITS, J.P.G.; GRIENSVEN, L.J.L.D. van. Ecology of thermophilic fungi in mushroom compost, with emphasis on Scytalidium thermophilum and Agaricus bisporus mycelium. Applied and

Environmental Microbiology, London, v.60, n.2, p.454458, 1994.

TOMIZAWA, M.M.; DIAS, E.S.; ASSIS, L.J.; GOMIDE, P.H.O.; SANTOS, J.B. Genetic variability of mushroom isolates Agaricus blazei using markers RAPD. Ciência e Agrotecnologia, Lavras, v.31, n.4, p.1242-1249, jul./ago. 2007.

URBEN, A.F. Produção de cogumelos por meio de tecnologia chinesa modificada. Brasília: Embrapa, 2001. $151 \mathrm{p}$.

WASSER, S.P.; DIDUKH, M.Y.; AMAZONAS, M.A.L.; NEVO, E.; STAMETS, P.; EIRA, A.F. Is a widely cultivated culinary-medicinal Royal Sun Agaricus (the Himematsutake Mushroom) indeed Agaricus blazei Murrill? International Journal of Medicinal

Mushrooms, v.4, p.267-290, 2002. 